\title{
Protocol
}

\section{Alkaline Agarose Gel Electrophoresis}

\author{
Michael R. Green and Joseph Sambrook
}

Alkaline agarose gels are run at high $\mathrm{pH}$, which causes each thymine and guanine residue to lose a proton and thus prevents the formation of hydrogen bonds with their adenine and cytosine partners. The denatured DNA is maintained in a single-stranded state and migrates through an alkaline agarose gel as a function of its size. Other denaturants such as formamide and urea do not work well because they cause the agarose to become rubbery.

\section{MATERIALS}

It is essential that you consult the appropriate Material Safety Data Sheets and your institution's Environmental Health and Safety Office for proper handling of equipment and hazardous materials used in this protocol.

RECIPES: Please see the end of this protocol for recipes indicated by $<R>$. Additional recipes can be found online at http://cshprotocols.cshlp.org/site/recipes.

Agarose

Alkaline agarose gel electrophoresis buffer $(10 \times)<\mathrm{R}>$

Dilute the $10 \times$ alkaline agarose gel electrophoresis buffer with $\mathrm{H}_{2} \mathrm{O}$ to generate a $1 \times$ working solution immediately before use in Step 3 below. Use the same stock of 10x alkaline agarose gel electrophoresis buffer to prepare the alkaline agarose gel and the $1 \times$ working solution of alkaline electrophoresis buffer.

Alkaline gel-loading buffer $(6 \times)<\mathrm{R}>$

DNA samples (usually radiolabeled)

EDTA (0.5 M, pH 8.0; optional; see Step 4)

Electrophoresis buffer (TBE; $0.5 \times)<\mathrm{R}>$

Ethanol

Ethidium bromide or SYBR Gold staining solution, prepared in TBE electrophoresis buffer:

Ethidium bromide solution: $0.5 \mu \mathrm{g} / \mathrm{mL}$ in $0.5 \times \mathrm{TBE}$

SYBR Green I stock solution, diluted 1:10,00 in $0.5 \times$ TBE

For a discussion of staining agarose gels, see Introduction: Analysis of DNA by Agarose Gel Electrophoresis (Green and Sambrook 2019a).

Neutralizing solution for alkaline agarose gels $<\mathrm{R}>$

Sodium acetate (3 $\mathrm{M}, \mathrm{pH} 5.2)$

Trichloroacetic acid (TCA) $(7 \%)$

From the Molecular Cloning collection, edited by Michael R. Green and Joseph Sambrook. 


\section{Equipment}

\section{METHOD}

\section{Preparing and Running Alkaline Gels}

1. Prepare the agarose solution by adding the appropriate amount of powdered agarose (see Protocol: Agarose Gel Electrophoresis [Green and Sambrook 2019b]) to a measured quantity of $\mathrm{H}_{2} \mathrm{O}$ in an Erlenmeyer flask or a glass bottle.

2. Loosely plug the neck of the Erlenmeyer flask with KimWipes. When using a glass bottle, make sure that the cap is loose. Heat the slurry in a boiling water bath or a microwave oven until the agarose dissolves.

Heat the slurry for the minimum time required to allow all of the grains of agarose to dissolve. Undissolved agarose appears as small "lenses" or translucent chips floating in the solution. Wearing an oven mitt, carefully swirl the bottle or flask from time to time to make sure that any grains sticking to the walls enter the solution. Check that the volume of the solution has not been decreased by evaporation during boiling; replenish with $\mathrm{H}_{2} \mathrm{O}$ if necessary.

3. Cool the clear solution to $55^{\circ} \mathrm{C}$. Add 0.1 volume of $10 \times$ alkaline agarose gel electrophoresis buffer, and immediately pour the gel as described in Protocol: Agarose Gel Electrophoresis (Green and Sambrook 2019b). After the gel is completely set, mount it in the electrophoresis tank, and add freshly made $1 \times$ Alkaline electrophoresis buffer until the gel is just covered.

Do not add ethidium bromide because the dye will not bind to DNA at high $\mathrm{pH}$.

The addition of $\mathrm{NaOH}$ to a hot agarose solution causes hydrolysis of the polysaccharide. For this reason, the agarose is first melted in $\mathrm{H}_{2} \mathrm{O}$ and then made alkaline by the addition of $\mathrm{NaOH}$ just before the gel is poured.

4. Collect the DNA samples by standard precipitation with ethanol. Dissolve the damp precipitates of DNA in 10-20 $\mu \mathrm{L}$ of $1 \times$ gel buffer. Add 0.2 volume of $6 \times$ alkaline gel-loading buffer.

Alternatively, if the volumes of the original DNA samples are small $(<15 \mu \mathrm{L})$, add $0.5 \mathrm{M}$ EDTA ( $p H$ 8.0) to a final concentration of $10 \mathrm{~mm}$, followed by 0.2 volume of $6 \times$ Alkaline gel-loading buffer.

It is important to chelate all $\mathrm{Mg}^{2+}$ with EDTA before adjusting the electrophoresis samples to alkaline conditions. In solutions of high $\mathrm{pH}, \mathrm{Mg}^{2+}$ forms insoluble $\mathrm{Mg}(\mathrm{OH})_{2}$ precipitates that entrap DNA. 
M.R. Green and J. Sambrook

5. Load the DNA samples dissolved in 6× Alkaline gel-loading buffer into the wells of the gel as described in Protocol: Agarose Gel Electrophoresis [Green and Sambrook 2019b]. Start the electrophoresis at $<3.5 \mathrm{~V} / \mathrm{cm}$, and, when the bromocresol green has migrated into the gel $\sim 0.5-1 \mathrm{~cm}$, turn off the power supply and place a glass plate on top of the gel. Continue electrophoresis until the bromocresol green has migrated approximately two-thirds of the length of the gel.

6. Process the gel according to one or more of the procedures described below, as appropriate for the goal of the experiment.

i. To stain the gel, proceed to Step 7.

ii. To perform Southern hybridization, proceed to Step 9.

Staining the Gel

7. Soak the gel in neutralizing solution for $45 \mathrm{~min}$ at room temperature.

8. Stain the neutralized gel with $0.5 \mu \mathrm{g} / \mathrm{mL}$ ethidium bromide in $0.5 \times \mathrm{TBE}$ or with a SYBR dye.

Southern Hybridization

9. Soak the gel in neutralizing solution for $45 \mathrm{~min}$ at room temperature, and transfer the DNA to an uncharged nitrocellulose or nylon membrane as described in Protocol: Southern Blotting (Green and Sambrook 2021a).

Alternatively, transfer the DNA directly (without soaking the gel) from the alkaline agarose gel to a charged nylon membrane (see Protocol: Southern Blotting [Green and Sambrook 2021a]).

10. Detect the target sequences in the immobilized DNA by hybridization to an appropriate labeled probe (Protocol: Southern Hybridization of Radiolabeled Probes to Nucleic Acids Immobilized on Membranes [Green and Sambrook 2021b]).

For autoradiography of wet gels proceed to Step 11. For autoradiography of dried gels proceed to Step 15.

\section{Autoradiography}

In many cases, DNA analyzed by alkaline agarose gel electrophoresis is labeled with ${ }^{32} \mathrm{P}$, which can be detected by autoradiography. Drying the gel (see below) greatly improves the sharpness of the autoradiographic image and slightly increases the sensitivity by reducing aqueous quenching. However, if there is sufficient radiolabel in the DNA and the sharpness of the bands is not a major concern or if the DNA band is to be recovered from the gel, the gel can be autoradiographed without drying.

\section{Autoradiography of Wet Gels}

11. After completion of electrophoresis, place the gel on a glass plate.

12. Dry the surface of the gel and the surrounding glass plate with KimWipes.

13. Attach luminescent markers to the glass plate.

14. Capture an image of the radioactivity emitted from the gel on a phosphorimager (see Introduction: Autoradiography and Phosphorimaging [Green and Sambrook 2020]).

\section{Autoradiography of Dried Gels}

15. Soak the gel in 7\% TCA for $30 \mathrm{~min}$ at room temperature. Agitate the solution every few minutes to ensure that the gel remains covered with fluid.

16. Mount the gel on a glass plate and dry it for several hours under layers of paper towels weighted with another glass plate, or place the gel on two sheets of Whatman 3MM filter paper and dry it under vacuum on a gel dryer.

i. Heat should not be used because the gel may melt. 
17. Mount the dried gel on a piece of $3 \mathrm{MM}$ paper, and attach luminescent markers to align the image with the gel.

18. Capture an image of the radioactivity emitted from the gel on a phosphorimager (see Introduction: Autoradiography and Phosphorimaging [Green and Sambrook 2020]).

\section{DISCUSSION}

The use of alkaline agarose gel electrophoresis reached its maximum in the early 1980s, when reagents and enzymes were less reliable than today and cloners were of necessity more vigilant about quality control. (For a brief history of its development, see Box 1.) At that time, alkaline agarose electrophoresis was used routinely to:

- check for nicking activity in enzyme preparations used for molecular cloning

- calibrate the reagents used in nick translation of DNA

- measure the size of first and second strands of cDNA synthesized by reverse transcriptase

- analyze the size of the DNA strand after digestion of DNA-RNA hybrids with nuclease S1 (Favaloro et al. 1980)

Nowadays, only the most compulsive investigators would use alkaline agarose electrophoresis to monitor the quality of enzymes. Nevertheless, the technique remains important because of its speed and accuracy in measuring the length of DNA strands by Southern hybridization.

Bear the following points in mind when working with alkaline gels.

- Alkaline gels draw more current than neutral gels at comparable voltages and heat up during the run. Alkaline agarose electrophoresis should therefore be performed at $<3.5 \mathrm{~V} / \mathrm{cm}$. A glass plate placed on top of the gel after the run is started slows the diffusion of the bromocresol green dye out of the gel and prevents the gel from detaching and floating in the buffer.

- Partial base hydrolysis of the agarose causes single-stranded DNA to migrate as an uneven band, often at slower rates toward the bottom of the gel and at faster rates toward the top of the gel (Favaloro et al. 1980). If this is a problem, check the buffer to ensure that the final $\mathrm{NaOH}$ concentration is $50 \mathrm{~mm}$; make sure that the gel solution is cooled to $60^{\circ} \mathrm{C}$ before adding the $10 \times$ alkaline agarose gel electrophoresis buffer, and cool the gel to room temperature before installing it in the electrophoresis tank and covering it with alkaline electrophoresis buffer.

- It is not strictly necessary to denature the DNA with base before electrophoresis. The exposure of the samples to the alkaline conditions in the gel is usually enough to render the DNA singlestranded.

\section{BOX 1. HISTORICAL FOOTNOTE}

Alkaline agarose electrophoresis was developed in Bill Studier's laboratory at Brookhaven National Laboratory as a replacement for laborious alkaline gradient centrifugation of bacteriophage T7 DNA (McDonell et al. 1977). The first alkaline horizontal gels were equipped with agarose wicks. Subsequently, Studier developed a gel box with removable slot-formers that allowed the gel to be poured, soaked, stained, and viewed in situ. This type of apparatus was simple to construct and became extremely popular for both alkaline and neutral electrophoresis in the years before commercially manufactured gel boxes became available.

Bromophenol blue is quickly bleached by incubation at high $\mathrm{pH}$ and is therefore unsatisfactory as a tracking dye in alkaline agarose gels. The superior qualities of bromocresol green were discovered in a systematic screen of an ancient collection of dyes languishing in the Brookhaven Laboratory chemical store. 
M.R. Green and J. Sambrook

\section{RECIPES}

\section{Alkaline Agarose Gel Electrophoresis Buffer}

For $10 \times$ solution: Add $50 \mathrm{ml}$ of $10 \mathrm{~N} \mathrm{NaOH}$ and $20 \mathrm{ml}$ of $0.5 \mathrm{M}$ EDTA (pH 8.0) to $800 \mathrm{ml}$ of $\mathrm{H}_{2} \mathrm{O}$ and then adjust the final volume to 1 liter. Dilute the $10 \times$ alkaline agarose gel electrophoresis buffer with $\mathrm{H}_{2} \mathrm{O}$ to generate a $1 \times$ working solution immediately before use. Use the same stock of $10 \times$ alkaline agarose gel electrophoresis buffer to prepare the alkaline agarose gel and the $1 \times$ working solution of alkaline electrophoresis buffer.

\section{Alkaline Gel-Loading Buffer}

$300 \mathrm{~mm} \mathrm{NaOH}$

$6 \mathrm{~mm}$ EDTA

18\% (w/v) Ficoll (Type 400, Pharmacia)

$0.15 \%(\mathrm{w} / \mathrm{v})$ bromocresol green

$0.25 \%(\mathrm{w} / \mathrm{v})$ xylene cyanol

For a $6 \times$ buffer.

Neutralizing Solution for Alkaline Agarose Gels

1 M Tris-Cl (pH 7.6)

$1.5 \mathrm{M} \mathrm{NaCl}$

\section{TBE Buffer}

Prepare a $5 \times$ stock solution in $1 \mathrm{~L}^{\text {of }} \mathrm{H}_{2} \mathrm{O}$ :

$54 \mathrm{~g}$ of Tris base

$27.5 \mathrm{~g}$ of boric acid

$20 \mathrm{~mL}$ of $0.5 \mathrm{M}$ EDTA (pH 8.0)

The $0.5 \times$ working solution is $45 \mathrm{~mm}$ Tris-borate/ $1 \mathrm{~mm}$ EDTA.

TBE is usually made and stored as a $5 \times$ or $10 \times$ stock solution. The $\mathrm{pH}$ of the concentrated stock buffer should be $\sim 8.3$. Dilute the concentrated stock buffer just before use and make the gel solution and the electrophoresis buffer from the same concentrated stock solution. Some investigators prefer to use more concentrated stock solutions of TBE ( $10 \times$ as opposed to $5 \times$ ). However, $5 \times$ stock solution is more stable because the solutes do not precipitate during storage. Passing the $5 \times$ or $10 \times$ buffer stocks through a $0.22-\mu \mathrm{m}$ filter can prevent or delay formation of precipitates.

\section{REFERENCES}

Favaloro J, Treisman R, Kamen R. 1980. Transcription maps of polyoma virus-specific RNA: Analysis by two-dimensional nuclease S1 gel mapping. Methods Enzymol 65: 718-749.

Green MR, Sambrook J. 2019a. Analysis of DNA by agarose gel electrophoresis. Cold Spring Harb Protoc doi:10.1101/pdb.top100388.

Green MR, Sambrook J. 2019b. Agarose gel electrophoresis. Cold Spring Harb Protoc doi:10.1101/pdb.prot100404.

Green MR, Sambrook J. 2020. Autoradiography and phosphorimaging. Cold Spring Harb Protoc doi:10.1101/pdb.top100446.
Green MR, Sambrook J. 2021a. Southern blotting. Cold Spring Harb Protoc doi:10.1101/pdb.prot100487.

Green MR, Sambrook J. 2021b. Southern hybridization of radiolabeled probes to nucleic acids immobilized on membranes. Cold Spring Harb Protoc doi:10.1101/pdb.prot100495.

McDonell MW, Simon MN, Studier FW. 1977. Analysis of restriction fragments of T7 DNA and determination of molecular weights by electrophoresis in neutral and alkaline gels. J Mol Biol 110: 119-146. 


\section{Alkaline Agarose Gel Electrophoresis}

Michael R. Green and Joseph Sambrook

Cold Spring Harb Protoc; doi: 10.1101/pdb.prot100438

\begin{tabular}{|c|c|}
\hline $\begin{array}{r}\text { Email Alerting } \\
\text { Service }\end{array}$ & Receive free email alerts when new articles cite this article - click here. \\
\hline $\begin{array}{r}\text { Subject } \\
\text { Categories }\end{array}$ & $\begin{array}{l}\text { Browse articles on similar topics from Cold Spring Harbor Protocols. } \\
\text { Electrophoresis ( } 57 \text { articles) } \\
\text { Electrophoresis of DNA (47 articles) } \\
\text { Electrophoresis of Nucleic Acids (62 articles) } \\
\text { Electrophoresis of Nucleic Acids, general (49 articles) } \\
\text { Electrophoresis, general (130 articles) } \\
\text { Molecular Biology, general (1293 articles) }\end{array}$ \\
\hline
\end{tabular}

